\title{
Advances in the Treatment of Depression
}

\author{
Paul E. Holtzheimer III and Charles B. Nemeroff \\ Department of Psychiatry and Behavioral Sciences, Emory University, Atlanta, Georgia 30322
}

\begin{abstract}
Summary: Depression is a highly prevalent and disabling condition associated with significant morbidity and mortality. Currently available treatments for depression include tricyclic antidepressants, monoamine oxidase inhibitors, selective serotonin reuptake inhibitors, serotonin norepinephrine reuptake inhibitors, various atypical antidepressants, and electroconvulsive therapy. Although these treatments are effective, a significant number of patients do not respond or achieve sustained remission despite aggressive management. Advances in the neurobiology of depression have suggested a number of novel targets for antidepressant treatment. Based on an improved understanding of the neurobiology of depression, several novel pharmacologic and nonpharmacologic interventions are being developed. Pharmacologic developments include CRF antagonists, glucocorticoid receptor antagonists, sub-
\end{abstract}

stance $\mathrm{P}$ receptor antagonists, NMDA glutamate receptor antagonists, transdermal selegiline, so-called "triple" reuptake inhibitors, and augmentation of typical antidepressant medications with atypical antipsychotics. Nonpharmacologic advances have largely involved focal brain stimulation techniques including vagus nerve stimulation, transcranial magnetic stimulation, magnetic seizure therapy, and deep brain stimulation. For the most part, the data on these treatments are preliminary, and more study is needed to clarify their potential clinical benefit. However, it is clear that further study of the neurobiology of depression will continue to provide a rationale for developing innovative targets for antidepressant therapies. Key Words: Depression, antidepressant treatment, electroconvulsive therapy, neuropsychopharmacology, focal brain stimulation.

\section{INTRODUCTION}

Depression is one of the most common neuropsychiatric conditions, with a lifetime prevalence approaching $17 \%{ }^{1}$ Depression also ranks as one of the most significant causes of disability worldwide, second only to ischemic heart disease. ${ }^{2}$ Fortunately, depression is highly treatable. Pharmacotherapy, certain forms of psychotherapy and electroconvulsive therapy (ECT) have all shown antidepressant efficacy and can significantly improve quality of life of patients. Unfortunately, despite clear benefits for these treatments, many problems and unanswered questions remain.

Although medications, psychotherapy, and ECT can all be effective in treating depression, a significant number of patients do not respond fully to available treatments. Almost half of depressed patients continue to have some residual depressive symptoms despite adequate treatment, ${ }^{3}$ and up to $20 \%$ may show minimal or no response to even the most aggressive interven-

Address correspondence and reprint requests to Paul E. Holtzheimer III, M.D., Fuqua Center for Late-Life Depression, 1841 Clifton Road Northeast, Fourth Floor, Atlanta, GA 30329. E-mail: pholtzh@emory.edu. tions. ${ }^{4-6}$ Other patients are unable to tolerate currently available treatments. For patients who can tolerate and eventually respond to current treatments, time to response may take several weeks, and relapse is common. Long-term prophylactic treatment is often required to limit number and severity of depressive episodes over time. Research into the neurobiological underpinnings of mood disorders has progressed rapidly over the last several decades, and major strides have been made in understanding the neurochemical, neuroanatomical, and genetic bases for depression and related disorders. This work has served to suggest promising new directions for antidepressant treatment development.

In this review, we highlight developing treatments for depression based on an expanding neurobiological understanding of mood disorders. We first discuss current evidence-based treatments for depression including medications that modulate monoaminergic neurotransmission and electroconvulsive therapy. [Although a growing database supports a neurobiological basis for the efficacy of certain psychotherapies (such as cognitive behavioral therapy), ${ }^{7,8}$ a review of this literature is beyond the scope of this article.] Next, we review several promising new treatments that will be presented in two groups: pharmacologic interventions 
TABLE 1. Established Antidepressant Treatments

\begin{tabular}{|c|c|c|}
\hline Class & $\begin{array}{l}\text { Available in } \\
\text { United States }\end{array}$ & Level of Support \\
\hline TCAs & $\begin{array}{l}\text { Amitriptyline } \\
\text { Amoxapine } \\
\text { Clomipramine } \\
\text { Desipramine } \\
\text { Doxepin } \\
\text { Imipramine } \\
\text { Nortriptyline } \\
\text { Protriptyline } \\
\text { Trimipramine }\end{array}$ & $\begin{array}{l}\text { Multiple randomized } \\
\text { placebo-controlled } \\
\text { trials }\end{array}$ \\
\hline MAOIs & $\begin{array}{l}\text { Isocarboxazid } \\
\text { Phenelzine } \\
\text { Selegiline (oral) } \\
\text { Tranylcypromine }\end{array}$ & $\begin{array}{l}\text { Multiple randomized } \\
\text { placebo-controlled } \\
\text { trials }\end{array}$ \\
\hline SSRIs & $\begin{array}{l}\text { Citalopram } \\
\text { Escitalopram } \\
\text { Fluoxetine } \\
\text { Fluvoxamine } \\
\text { Paroxetine } \\
\text { Sertraline }\end{array}$ & $\begin{array}{l}\text { Multiple randomized } \\
\text { placebo-controlled } \\
\text { trials }\end{array}$ \\
\hline SNRIs & $\begin{array}{l}\text { Duloxetine } \\
\text { Venlafaxine }\end{array}$ & $\begin{array}{l}\text { Multiple randomized } \\
\text { placebo-controlled } \\
\text { trials }\end{array}$ \\
\hline Atypical & $\begin{array}{l}\text { Bupropion } \\
\text { Mirtazapine } \\
\text { Nefazodone } \\
\text { Trazodone }\end{array}$ & $\begin{array}{l}\text { Multiple randomized } \\
\text { placebo-controlled } \\
\text { trials }\end{array}$ \\
\hline ECT & & $\begin{array}{l}\text { Multiple randomized } \\
\text { placebo-controlled } \\
\text { trials }\end{array}$ \\
\hline
\end{tabular}

and brain stimulation techniques. This review will show how continued study of the biology of depression holds great promise for providing the rationale for the development of novel treatment strategies.

\section{ESTABLISHED SOMATIC TREATMENTS FOR DEPRESSION}

\section{Modulation of monoaminergic neurotransmission}

A myriad of controlled trials have established the antidepressant efficacy of medications that modulate monoaminergic neurotransmission (Table 1), primarily the serotonin and norepinephrine systems. These medications typically act by inhibiting reuptake of norepinephrine and/or serotonin from the synapse, inhibiting monoamine oxidase (which degrades these neurotransmitters) or acting at receptors that modulate monoaminergic transmission. Monoaminergic modulators generally include the tricyclic and tetracyclic antidepressants (TCAs), monoamine oxidase inhibitors (MAOIs), selective serotonin reuptake inhibitors (SSRIs), serotonin/norepinephrine reuptake inhibitors (SNRIs) and various "atypical" antidepressants with less well-described mechanisms of action.

TCAs are among the oldest antidepressant medications available and were, for many years, the pharmacologic treatment of choice for depression. A substantial literature demonstrates antidepressant efficacy for these medications. ${ }^{9,10}$ As a class, these agents are potent inhibitors of norepinephrine and/or serotonin reuptake into the presynaptic terminal. These medications also tend to block muscarinic cholinergic receptors and, as a result, are associated with anticholinergic side effects including dry mouth, dry eyes, constipation, blurred vision, urinary hesitancy, mild cognitive disturbance, and tachycardia. They also have antihistamine effects resulting in sedation and weight gain. Because of these side effects (and the considerable cardiac toxicity observed after TCA overdose), the TCAs have largely been replaced by other antidepressants as first-line agents in the treatment of depression.

Irreversible nonselective MAOIs are also among the oldest available antidepressant medications. The MAOIs prevent the degradation of all monoamines within the presynaptic terminal. These agents are clearly efficacious in depression. ${ }^{11}$ Importantly, MAOIs have also been shown to be especially effective in the treatment of "atypical" depression which accounts for $15-20 \%$ of major depression; atypical depressive episodes are characterized by substantial mood reactivity and "reverse" neurovegetative symptoms (increased sleep, increased appetite). These medications are limited by two to three times per day dosing, a less-than-favorable side effect profile and the tyramine-free diet required with their use. As well, MAOIs can interact with other agents that affect the monoaminergic systems to produce synergistic - and dangerous-effects. Table 1 lists MAOIs available in the U.S.

Because of their relatively benign side effect profile and limited drug-drug interactions, the SSRIs have largely replaced the TCAs and MAOIs as first-line agents in the treatment of depression. ${ }^{12}$ SSRIs strongly and selectively inhibit the reuptake of serotonin into the presynaptic terminal. As a class, they have little effect on norepinephrine reuptake and little to no effect on cholinergic or histaminergic function. However, their robust proserotonergic activity results in several, relatively unique, side effects including gastrointestinal distress (nausea, diarrhea, constipation), insomnia, nervousness and agitation, and sexual dysfunction. Although these side effects are often tolerable and/or time-limited in most patients, they lead to discontinuation in a substantial minority of treated subjects. Numerous randomized controlled trials have demonstrated the efficacy of these agents for depression and several anxiety disorders. ${ }^{12}$

Serotonin/norepinephrine reuptake inhibitors were designed to provide the pharmacological benefit of dual reuptake blockade exemplified by certain TCAs without their characteristic side effects. Currently, only two SNRIs, venlafaxine and duloxetine, are clinically available in the U.S., although a third, milnacipran, is avail- 
able in several countries in Europe and Asia. Venlafaxine has clear efficacy in the treatment of depression ${ }^{13}$ and certain anxiety disorders, such as generalized anxiety disorder. ${ }^{14,15}$ In its immediate release form, the side effects of venlafaxine (mostly similar to SSRIs) can occasionally be severe and limit its tolerability. ${ }^{16} \mathrm{An}$ extended release version is much better tolerated, although still associated with occasional side effects, including exacerbation of hypertension, and the question of overdose death liability and adverse effects on the heart remain unresolved. ${ }^{17-20}$ Duloxetine is the newest SNRI available, and as such its tolerability and efficacy in clinical populations is less well described. However, current data indicate that it is indeed an effective antidepressant medication with good tolerability, even in "sensitive" groups such as the elderly. ${ }^{21,22}$

"Atypical" antidepressants (bupropion, mirtazapine, nefazodone, and trazodone) are also widely used in the treatment of depression. In general, the mechanisms of action for these medications are poorly understood but still suggest modulation of monoaminergic systems. Bupropion has been available for many years and appears to be relatively weak in its effects on serotonin, norepinephrine or dopamine transporters. However, its efficacy is well documented and equal to that of SSRIs, and its side effects are limited. ${ }^{23}$ The most significant side effect related to immediate-release bupropion is a slightly decreased seizure threshold such that use in populations with higher risk for seizure is contraindicated; there are, however, data suggesting that slower release forms of the medication may be less likely to cause seizures. In addition, there is some evidence that bupropion may counteract the sexual side effects of SSRIs when used in combination. ${ }^{24}$ Mirtazapine, which may act at several pre- and postsynaptic serotonin and $\alpha_{2}$ adrenergic receptors, is efficacious in treating depression and is relatively well tolerated. ${ }^{25}$ Its most significant side effects are sedation and weight gain, which decrease in severity with increasing doses. Nefazodone is a potent blocker of 5- $\mathrm{HT}_{2}$ serotonin receptors and a weak inhibitor of serotonin and norepinephrine reuptake. ${ }^{26,27}$ This agent is an effective antidepressant and has shown efficacy in treating chronic depression. ${ }^{28}$ Unfortunately, nefazodone is rarely associated with lethal hepatitis, and its clinical use is now limited. ${ }^{29}$ Trazodone, which is structurally similar to nefazodone, is also efficacious in the treatment of depression, although its major side effect of sedation limits its use. This agent is still frequently used as a sedative-hypnotic, although the data supporting this use are limited. ${ }^{30}$

\section{Electroconvulsive therapy}

Electroconvulsive therapy (ECT; Table 1) is generally considered to be the most efficacious acute treatment for depression $^{31,32}$ and has the longest history of continued use of all available treatments. With ECT, an electric current is generated in the brain using electrodes placed on the scalp, and this current induces a generalized seizure. Although this aspect of the treatment has remained unchanged since its introduction, advances in anesthesiology have greatly improved the safety and tolerability of ECT. Response rates with ECT, even in treatmentresistant patients, can be as high as $50-90 \% .{ }^{33-36}$ ECT reduces suicide attempt rates and has been shown to reduce overall mortality rates in depressed patients over 3 years of follow-up. ${ }^{33,37}$ Despite its potential benefits, ECT still has significant risks and side effects including post-ictal confusion, transient memory disturbance, and cardiopulmonary complications. , $38,39^{-3}$

Bitemporal ECT remains the gold-standard for ECT in terms of efficacy-no other antidepressant treatment or ECT electrode placement has shown superiority to bitemporal ECT in the treatment of depression. However, bitemporal ECT is also associated with significant $\operatorname{cog}$ nitive side effects including retrograde and anterograde amnesia and confusion. ${ }^{40,41}$ Other electrode placements have attempted to decrease the side effects of ECT without compromising efficacy. Both right unilateral and bifrontal lead placements have shown efficacy in treating depression with fewer cognitive side effects than bitemporal ECT. ${ }^{41,42}$ Despite this, the side effects of ECT still limit its use. Also, although ECT is effective as an acute treatment, it is associated with a high relapse rate, with some investigators claiming a $4 \%$ per day worsening of depression symptom severity after completion of a treatment regimen. ${ }^{43}$

The mechanism of action of ECT is unknown, although data suggest that ECT may act through effects on monoaminergic systems (including dopamine, serotonin, and down-regulation of $\beta$ adrenergic receptors), by reducing corticotropin-releasing factor (CRF) availability, ${ }^{44}$ or by effects on other neurotrophic factors and neuroendocrine systems (for review see Wahlund and von Rosen). ${ }^{45}$ ECT also has anticonvulsant effects that have been related to its efficacy. ${ }^{46}$

\section{ADVANCES IN THE TREATMENT OF DEPRESSION}

\section{Pharmacological interventions}

Modulators of CRF and glucocorticoids. Psychological and physiological stress is known to precipitate depression in vulnerable individuals. In mammals, the stress response is largely coordinated by CRF, the neuropeptide that controls the hypothalamic-pituitary-adrenal (HPA) axis. Neurons in the paraventricular nucleus of the hypothalamus release CRF into the hypothalamohypophysial portal system. CRF then stimulates adrenocorticotropin (ACTH) release from the anterior pituitary into the systemic circulation which in turn stimulates the adrenal cortex to secrete glucocorticocoids. Outside of 
TABLE 2. Emerging Antidepressant Treatments: Pharmacotherapy

\begin{tabular}{|c|c|c|c|}
\hline Class & Examples & $\begin{array}{l}\text { Availability in } \\
\text { United States }\end{array}$ & Level of Support/Comments \\
\hline \multirow[t]{6}{*}{$\mathrm{CRF}_{1}$ antagonists } & R121919 & No & $\begin{array}{l}\text { Open data supporting antidepressant effects; liver } \\
\text { toxicity precludes use; preclinical data support } \\
\text { antidepressant-like and anxiolytic activity (in } \\
\text { stressed animals) }\end{array}$ \\
\hline & CP154,526 & No & $\begin{array}{l}\text { Preclinical data support antidepressant-like and } \\
\text { anxiolytic activity (in stressed animals) }\end{array}$ \\
\hline & Antalarmin & No & $\begin{array}{l}\text { Preclinical data support antidepressant-like and } \\
\text { anxiolytic activity (in stressed animals) }\end{array}$ \\
\hline & DMP-695/696 & No & $\begin{array}{l}\text { Preclinical data support anxiolytic activity (in } \\
\text { stressed animals) }\end{array}$ \\
\hline & CRA1000/CRA1001 & No & $\begin{array}{l}\text { Preclinical data support anxiolytic activity (in } \\
\text { stressed animals) }\end{array}$ \\
\hline & SSR125543A & No & $\begin{array}{l}\text { Preclinical data support antidepressant-like and } \\
\text { anxiolytic activity (in stressed animals) }\end{array}$ \\
\hline $\begin{array}{l}\text { Glucocorticoid receptor } \\
\text { (type II) antagonist }\end{array}$ & Mifepristone (RU486) & Yes (off label) & $\begin{array}{l}\text { Open and limited placebo-controlled data support } \\
\text { antidepressant and/or antipsychotic activity }\end{array}$ \\
\hline \multirow[t]{3}{*}{$\begin{array}{l}\text { NK-1 receptor } \\
\text { antagonists }\end{array}$} & MK-869 & No & $\begin{array}{l}\text { Placebo-controlled studies show mixed results (one } \\
\text { positive, one negative) }\end{array}$ \\
\hline & L-759274 & No & $\begin{array}{l}\text { One placebo-controlled study suggests modest } \\
\text { antidepressant effects }\end{array}$ \\
\hline & CP-122721 & No & $\begin{array}{l}\text { Preliminary clinical data suggest antidepressant } \\
\text { effects }\end{array}$ \\
\hline \multirow[t]{2}{*}{ NMDA antagonists } & Amantadine & Yes (off label) & $\begin{array}{l}\text { Preliminary data suggest antidepressant effects when } \\
\text { used for augmentation }\end{array}$ \\
\hline & $\begin{array}{l}\text { Riluzole (glutamate } \\
\text { release inhibitor) }\end{array}$ & Yes (off label) & $\begin{array}{l}\text { Preliminary data suggest antidepressant effects in } \\
\text { bipolar patients; no data in MDD }\end{array}$ \\
\hline Transdermal MAOIs & Selegiline patch & Yes (off label) & Placebo-controlled studies show mixed results \\
\hline \multirow{2}{*}{$\begin{array}{l}\text { Triple reuptake } \\
\text { inhibitors }\end{array}$} & DOV 21,947 & No & Preclinical data support antidepressant-like effects \\
\hline & DOV 216,303 & No & $\begin{array}{l}\text { Preclinical data support antidepressant-like effects; } \\
\text { preliminary data support safety in humans }\end{array}$ \\
\hline $\begin{array}{l}\text { Atypical antipsychotic } \\
\text { augmentation }\end{array}$ & Multiple & Yes (off label) & $\begin{array}{l}\text { Multiple open and small placebo-controlled studies } \\
\text { support antidepressant effects }\end{array}$ \\
\hline
\end{tabular}

the HPA axis, however, CRF and CRF receptors have a widespread but heterogeneous distribution, including cortical, subcortical and brainstem regions. Importantly, CRF has been found to modulate not only the endocrine stress response but also autonomic, immunologic, and behavioral responses as well. ${ }^{47}$

The HPA axis exhibits hyperactivity in patients with depression and considerable evidence suggests that this is driven by increased activity of CRF pathways. ${ }^{48} \mathrm{~Pa}$ tients with depression exhibit a substantial elevation of CSF CRF concentrations compared with controls, and there is increased CRF mRNA expression and an increase in the number of CRF-containing neurons in the paraventricular nucleus of depressed patients versus controls. ${ }^{48}$ Further support for a role for CRF in the pathophysiology of depression is provided by data that antidepressants modify CRF activity. In a group of healthy volunteers, desipramine was shown to decrease CSF CRF concentrations. ${ }^{49}$ Fluoxetine and ECT have been reported to produce similar changes in depressed pa- tients. ${ }^{44}$ Taken together, these data support a potential role in treating depression for agents that directly reduce CRF activity and function.

Two main receptor subtypes for CRF have been identified. $\mathrm{CRF}_{1}$ receptors strongly bind $\mathrm{CRF}$, are widely distributed throughout the brain, and decreased activity of these receptors has been linked with less anxiety in animal models. ${ }^{47} \mathrm{CRF}_{2}$ receptors bind CRF less strongly than $\mathrm{CRF}_{1}$ receptors, have a widespread distribution that appears to have limited overlap with that of $\mathrm{CRF}_{1}$ receptors, and decreased activity has been linked with increased anxiety-like behaviors. ${ }^{47}$ Although most work to date has been devoted to developing selective $\mathrm{CRF}_{1}$ receptor antagonists as putative antidepressant/anxiolytics therapies, $\mathrm{CRF}_{2}$ agonists might offer an additional, useful target for novel treatments.

Several $\mathrm{CRF}_{1}$ antagonists have been developed, and they exhibit anxiolytic and antidepressant activity in animal models (Table 2; see Gutman et al. ${ }^{47}$ for a review). To date, only one agent (R121919) has published data on 
its use in depressed patients. ${ }^{50}$ This agent showed evidence of antidepressant activity ${ }^{50}$ but is no longer a viable drug candidate due to liver toxicity. However, these data do demonstrate important "proof of principle" for $\mathrm{CRF}_{1}$ receptor antagonists, an impetus to further studies of these agents.

Another neuroendocrine target for novel drug development is glucocorticoid synthesis inhibitors and glucocorticoid receptor blockade. The data are limited on agents that interfere with cortisol synthesis (such as ketaconozale, aminogluthemide, and metyrapone) but do suggest potential antidepressant effects; however, these agents are also associated with a number of unfavorable side effects. ${ }^{51}$ The best studied glucocorticoid receptor antagonist in depression is mifepristone (RU486; Table 2), which is a selective type II glucocorticoid receptor blocker. An early open study of mifepristone suggested antidepressant effects in four patients with severe, chronic depression. ${ }^{52}$ More recent studies have focused on the treatment of psychotic depression which is characteristically associated with hypercholesterolemia. ${ }^{53} \mathrm{~A}$ small crossover, placebo-controlled study and a larger open-label study showed notable antidepressant and antipsychotic effects for mifepristone ${ }^{54,55}$; the open-label study showed that a higher dose of mifepristone (600 or $1200 \mathrm{mg}$ ) was more effective than low dose $(50 \mathrm{mg}){ }^{55}$ Also, beneficial effects were seen within 7 days. In general, the most robust effects observed were on the psychotic symptoms as opposed to the core depressive symptoms. These data support the conduct of large, double-blind, placebo-controlled trials which are underway.

In summary, the role of the neuroendocrine stress response system in the pathophysiology of depression appears to be preeminent, and a number of novel antidepressant drugs that target this system have been identified. Although results to date are limited, this exciting direction for research holds promise, and a number of definitive clinical trials are underway.

Substance $\mathbf{P}$ antagonists. Neurokinins are a family of neuropeptides widely distributed in the CNS and the periphery that have been implicated in pain neurotransmission. Substance P (NK-1) is the most abundant and well studied of the mammalian neurokinins. Substance $P$ is found in neurons in the amygdala, hypothalamus, periaqueductal gray matter, locus ceruleus, and parabrachial nucleus, ${ }^{56}$ and is colocalized in certain serotonin- and norepinephrine-containing cell bodies. ${ }^{57-60}$ Substance $\mathrm{P}$ binds to several neurokinin receptor subtypes (NK-1, NK-2, NK-3, NKA, NKB). Administration of substance $\mathrm{P}$ to animals can elicit a behavioral and physiologic stress response and a "defense reaction." "61,62 Conversely, the behavioral and physiologic response to stress can be attenuated by substance P antagonists. ${ }^{63,64}$ CSF substance $\mathrm{P}$ levels are elevated in patients with depression, ${ }^{65-67}$ and decreased substance $\mathrm{P}$ levels have been reported to be associated with better response to antidepressants. ${ }^{66}$

In an initial placebo-controlled study of a substance $\mathrm{P}$ NK-1 receptor antagonist (MK-869), antidepressant effects were demonstrated. ${ }^{63}$ However, subsequent doubleblind placebo-controlled studies revealed no antidepressant efficacy of this compound. ${ }^{68}$ These discouraging results are difficult to reconcile. Another selective NK-1 receptor antagonists (L-759274) showed modest but statistically significant antidepressant effects in a placebocontrolled trial, ${ }^{69}$ and another agent (CP-122721) has shown clinical evidence of antidepressant effects. ${ }^{70}$ Generally, these drugs (Table 2) appear to be well tolerated.

NMDA glutamate receptor antagonists. Glutamate is recognized as the primary excitatory neurotransmitter in the brain. Glutamate receptors are divided into two types: ionotropic (including the NMDA, AMPA, and kainite receptors) and metabotropic (including a family of g-protein coupled receptors associated with adenyl cyclase and phosphoinositide second messenger systems). A growing database supports a role for excitatory glutamatergic neurotransmission in the pathophysiology of depression. ${ }^{71,72}$ As above, stress has been linked with depression, and it has been proposed that stress may contribute to depression by causing excitatory (primarily glutamatergic) neurotoxicity for cells in brain regions involved in mood regulation. Ionotropic glutamate receptor antagonists have been shown to decrease stress-induced atrophy in hippocampal neurons. ${ }^{73,74}$ Data also suggest amantadine (a nonselective NMDA receptor antagonist) may enhance antidepressant-like effects of typical antidepressants in animal models. ${ }^{75,76}$ Preclinical studies have shown that selective NMDA receptor antagonists have antidepressant-like effects in animal behavioral models (Table 2) ) $^{77,78}$ and that AMPA receptor potentiators may augment typical antidepressant effects. ${ }^{79}$ Riluzole, which inhibits glutamate release, may have antidepressant effects in patients with bipolar depression $^{80,81}$; however, this agent has not been tested in placebo-controlled trials or in patients with unipolar depression. Amantadine has shown very preliminary potential as an augmentation agent in treatment-resistant depression. ${ }^{82}$ Further clinical studies of other glutamatemodulating agents in depression appear warranted.

Transdermal selegiline. As above, MAOIs have clearly documented efficacy in depression, but their use is limited by dosing, side effects and the required tyramine-free diet. The majority of clinically available MAOIs are nonselective, irreversible inhibitors of both isozymes of monoamine oxidase (monoamine oxidases A and B). Oral selegiline (which is a selective, irreversible MAO-B inhibitor at lower doses, but nonselective at higher doses) has shown antidepressant efficacy in prior 
TABLE 3. Emerging Antidepressant Treatments: Focal Brain Stimulation

\begin{tabular}{|c|c|c|}
\hline $\begin{array}{l}\text { Type of } \\
\text { Stimulation }\end{array}$ & $\begin{array}{c}\text { Availability in } \\
\text { United States }\end{array}$ & Level of Support/Comments \\
\hline VNS & Yes & $\begin{array}{l}\text { Placebo-controlled data negative; however, long-term open data } \\
\text { support antidepressant effects in severely refractory patients }\end{array}$ \\
\hline TMS & No & $\begin{array}{l}\text { Multiple small placebo-controlled studies support at least } \\
\text { modest antidepressant effects; large, multi-center studies are } \\
\text { ongoing }\end{array}$ \\
\hline MST & No & Preliminary clinical data support potential antidepressant effects \\
\hline DBS & Yes (off label) & One small open study supports antidepressant effects \\
\hline
\end{tabular}

TMS $=$ transcranial magnetic stimulation.

studies-but only at doses where it shows nonselective MAOI activity (supporting a role for either both MAO isozymes or MAO-A in the pathophysiology of depression). ${ }^{83}$ Given that the dietary restrictions required with use of a nonselective MAOI are largely related to inhibition of mucosal MAO isozymes, a transdermal delivery system for selegiline was developed to allow selective targeting of brain MAOs. ${ }^{84}$ This treatment has shown antidepressant efficacy in three placebo-controlled trials $^{85,86}$ (data on file, Somerset Pharmaceuticals, Tampa, FL), though two other placebo-controlled trials have shown no benefit ${ }^{86}$ (data on file, Somerset Pharmaceuticals) (Table 2).

Triple reuptake inhibitors. As discussed above, most currently available antidepressant medications affect serotonin and/or norepinephrine activity (principally through blocking reuptake at the presynaptic terminal). However, it is highly probable that dopamine also plays a role in the pathophysiology of depression. ${ }^{87-90}$ Thus, interest has focused on developing antidepressant medications that effectively inhibit reuptake of dopamine in addition to serotonin and norepinephrine - such agents are referred to as "triple reuptake inhibitors." Two triple reuptake inhibitors (DOV 21,947 and DOV 216,303) (Table 2) have shown preclinical evidence for antidepressant like effects ${ }^{91,92}$; one follow-up study has shown that DOV 216,303 is safe and tolerable in humans. ${ }^{93}$ Further study of these agents is warranted.

Augmentation with atypical antipsychotics. Pharmacologic augmentation is common in the treatment of depression. ${ }^{94}$ Previous augmentation strategies have most often involved the combination of SSRIs with bupropion, ${ }^{95}$ addition of lithium, ${ }^{96}$ or addition of thyroid hormone. ${ }^{97}$ A novel augmentation strategy involves the use of atypical antipsychotics. Atypical antipsychotics were originally designed to treat schizophrenia with equal efficacy but fewer extrapyramidal side effects compared with typical antipsychotics (such as haloperidol and perphenazine)..$^{98}$ In the U.S., the currently available atypical antipsychotics are clozapine, olanzapine, risperidone, quetiapine, ziprasidone, and aripiprazole. These agents generally show weak blockade of the do- pamine 2 (D2) receptor and increased activity at serotonin and possibly glutamate receptors ${ }^{99}$; aripiprazole differs in that it functions as a partial agonist at the D2 receptor. These agents indeed have fewer extrapyramidal side effects compared with traditional antipsychotics and are associated with a much lower rate of tardive dyskinesia. ${ }^{98}$ However, drugs in this class have been associated with a unique and challenging set of side effects including weight gain, glucose intolerance, and serum lipid abnormalities. ${ }^{100}$

Since their introduction, the atypical antipsychotics have demonstrated efficacy in treating schizophrenia, ${ }^{101}$ as well as bipolar disorder (including manic, mixed, depressed, and maintenance phases of the illness). ${ }^{102}$ Specific drugs in this class have also been found to augment SSRI action in certain anxiety disorders, including obsessive-compulsive disorder $(\mathrm{OCD})^{103-105}$ and post-traumatic stress disorder (PTSD). ${ }^{106-108}$ Several reports suggest the atypical antipsychotics may also augment standard antidepressant medications, even in the absence of psychotic features in the depressive episode (Table 2). ${ }^{109-113}$

\section{Focal brain stimulation}

Neuroanatomical models of depression suggest dysfunction within a frontal cortical-subcortical-brainstem neural network in depressed patients. ${ }^{114-116}$ These models suggest that selective modulation of specific brain regions within this network could be beneficial in the treatment of depression. Most current treatments for depression (medications and ECT) do not act specifically at discrete brain regions. Surgical interventions for refractory depression do target specific brain regions ${ }^{117-120}$ but result in permanent lesions that cannot be adjusted or reversed. As a result, much interest has recently focused on focal brain stimulation therapies for depression (Table 3).

\section{Vagus nerve stimulation}

Vagus nerve stimulation (VNS) is accomplished through a surgical procedure that connects an electrical stimulator to a patient's left vagus nerve. This stimulator is then attached to a programmable pulse generator that is surgically implanted subcutaneously in the patient's 
chest. The stimulator can be programmed to deliver electrical pulses to the nerve at various frequencies and currents. Typically, stimulation parameters are 0.25 milliampules, $20-30 \mathrm{~Hz}, 250-$ to $500-\mu$ s pulse width, and an on/off cycle of $30 \mathrm{~s}$ on every 3-5 min. Side effects of VNS surgery and treatment are generally mild. ${ }^{121}$ Surgical complications are rare, with incision pain being the most commonly reported adverse event. Common side effects of treatment include voice hoarseness and coughing. In general, VNS appears to be well tolerated and acceptable to patients. VNS was originally approved by the Food and Drug Administration for treatment-resistant epilepsy ${ }^{122}$ and was recently approved for the adjunctive treatment of a major depressive episode that has not responded to at least four antidepressant medication trials.

The initial rationale for VNS in the treatment of depression was based on mood improvements reported by epileptic patients receiving VNS, ${ }^{123}$ and evidence that the antidepressant effects of ECT may be associated with its anticonvulsant effects. ${ }^{124}$ One open study and one double-blind study have shown antidepressant efficacy for VNS in epilepsy patients with comorbid depression. ${ }^{125,126}$ A single open study of VNS in 60 nonepileptic patients with treatment-resistant depression found a $31 \%$ response rate and $15 \%$ remission rate after 10 weeks. ${ }^{127}$ These response and remission rates were sustained at 1 year $^{128}$ and improved at 2 years after surgery. ${ }^{129}$ Based on these data, a large, sham-controlled study was conducted but failed to show statistically significant antidepressant effects for active $\mathrm{VNS}^{130}$; at the end of the initial 10-week evaluation period, response rate was $15 \%$ with VNS and $10 \%$ with sham. When all patients then received open, active VNS for up to 1 year, the response rate increased to $27 \%$ and remission rate was $16 \% .{ }^{131}$ These 1-year response and remission rates compared favorably to those of a medication management, observation-only comparison group of similarly treatment-resistant patients (13\% response and 7\% remission in the observation-only group). ${ }^{132}$ Longer term response, remission, and relapse data are not currently available for this group of patients.

The potential mechanisms of action of VNS in epilepsy and depression are currently unknown. However, the central projections of the vagus nerve via the nucleus tractus solitarius innervate multiple brain areas implicated in mood regulation, and functional brain imaging studies have confirmed that VNS alters activity of many of these cortical and subcortical regions. ${ }^{133}$ VNS may affect function of the GABA, ${ }^{134,135}$ dopamine ${ }^{136}$ and especially norepinephrine ${ }^{137-140}$ systems, although these data are not unequivocal. ${ }^{136}$ Importantly, effects on these neurotransmitter systems, when present, have not consistently been associated with therapeutic response. ${ }^{134}$

In summary, VNS is a relatively safe, well-tolerated treatment that may have efficacy when used chronically in patients with treatment-resistant depression. Current efficacy data are mixed, with a large, sham-controlled study finding no statistically significant acute antidepressant effects. However, long-term follow-up data suggest response and remission may increase over time in VNStreated patients, and that 1 -year response and remission rates may be statistically and perhaps clinically better than results achieved with "treatment-as-usual." However, no randomized, controlled data are yet available to support this conclusion. The long-term effects of VNS in treatment-resistant depression are unknown, and it is not yet clear which patients may be more or less likely to benefit from this treatment. Further study is clearly warranted given that even a small percentage of responders in this extremely treatment refractory patient population would be an important advance in the field.

\section{Transcranial magnetic stimulation}

Transcranial magnetic stimulation (TMS) uses a current passed through an electromagnetic coil on the scalp to create a brief, rapidly changing magnetic field. This magnetic field experiences little to no impedance from the scalp, skull and air, and is able to induce a small, focal electrical current within the underlying cortex, resulting in depolarization of cortical neurons. Whereas single-pulse TMS is an established diagnostic and research tool in humans, ${ }^{141}$ repetitive TMS (rTMS) has been most extensively studied as a possible treatment for depression. rTMS delivers several discrete electrical pulses to the cortex in a short period of time. This group of pulses is referred to as a "train" of stimuli and, typically, several trains of rTMS are delivered within a single session. By convention, high-frequency or "fast" rTMS refers to stimulation delivered at a rate higher than $1 \mathrm{~Hz}$, and low-frequency or "slow" rTMS refers to stimulation at frequencies of $1 \mathrm{~Hz}$ or slower. Fast rTMS applied to the motor cortex is associated with an increase in motor cortical excitability that persists beyond the end of stimulation, ${ }^{142}$ whereas slow rTMS is associated with a decrease in motor cortical excitability. ${ }^{143}$ TMS is typically "dosed" by reference to the patient's motor threshold (MT). The MT is defined as the intensity of single pulse TMS required to generate a motor response in one of the small hand muscles (often the abductor pollicis brevis or first dorsal interosseous) during half of a series of trials. No anesthesia is needed when giving rTMS (except in the case of magnetic seizure therapy (MST) discussed separately below). Although approved for the treatment of depression in Canada and other countries, in the U.S. rTMS is only available in clinical research trials.

The rationale for rTMS as a treatment for depression was initially based on a converging database implicating prefrontal cortical dysfunction in depression and showing focal neuromodulatory and behavioral effects of 
rTMS in animals and humans. Both neuroimaging and human stroke data have strongly supported a role for the dorsolateral prefrontal cortices (DLPFC) in depression, with both data sets suggesting that depression is associated with decreased activity of the left DLPFC. ${ }^{144-146}$ Combined with the excitatory effects of high-frequency rTMS over the motor cortex, it was suggested that rTMS might be used to increase function in this apparently hypoactive brain region in patients with depression. ${ }^{147}$ Such intervention was supported in principle by data on TMS in healthy subjects showing acute mood changes with stimulation of the dorsolateral prefrontal corticesalthough the direction of change was not consistent with the expected mood effects in depressed patients. ${ }^{148}$ Furthermore, rTMS showed behavioral changes in animals similar to those achieved with electroconvulsive shock and suggestive of an antidepressant effect. ${ }^{149}$

Several early, small open and controlled studies showed mild to moderate antidepressant effects with fast rTMS applied to the left DLPFC; see Burt et al. ${ }^{150}$ for a review. Some studies suggested potentially marked and rapid effects in patients with treatment-resistant depression. For example, Epstein et al. ${ }^{151}$ found a $56 \%$ response rate in 32 medication-resistant patients treated with five sessions of $10 \mathrm{~Hz}$, left DLPFC rTMS at $110 \%$ MT intensity. These encouraging results led to the conduct of several, slightly larger sham-controlled studies. Based on these studies, a number of meta-analyses, each using slightly different inclusion/exclusion criteria and statistical methods, have agreed that high-frequency ( $\geq 5$ $\mathrm{Hz}$ ), left DLPFC rTMS given for at least 10 daily sessions results in statistically significant antidepressant effects. ${ }^{150,152-154}$ However, the response rates with rTMS have not consistently matched those seen in earlier open trials; Holtzheimer et al. ${ }^{152}$ for example, found the average response rate (defined as a decrease of $50 \%$ or more in depression ratings) across all studies using high-frequency, left DLPFC rTMS was $18 \%$ for active rTMS and $2 \%$ for sham rTMS. It therefore remains unclear whether antidepressant effects of rTMS, even if statistically significant, are clinically meaningful. ${ }^{155}$

A number of factors should be considered in interpreting the available rTMS data. First, it should be noted that the difference between active and sham rTMS response and remission rates is on the order of that seen in metaanalyses of antidepressant medication trials. ${ }^{13,156} \mathrm{Sec}$ ond, nearly every prior rTMS treatment study has exclusively included patients with treatment-resistant depression. Having failed at least one adequate antidepressant medication trial has been shown to significantly reduce the likelihood of responding to other treatments, including ECT. ${ }^{3,36}$ Third, other patient factors may affect likelihood of response to rTMS. Pooled data suggest that presence of psychosis and older age are associated with a lower response rate with TTMS $^{157}$; as well, shorter duration of current episode may predict response to rTMS. ${ }^{158}$ Fourth, it is unlikely that the rTMS studies to date have used optimized antidepressant treatment parameters. Increased stimulation intensity, more daily treatment sessions, and greater overall number of rTMS pulses delivered are likely related to greater antidepressant efficacy. ${ }^{157}$ A recently completed sham-controlled study of rTMS used 15 sessions of $10 \mathrm{~Hz}, 110 \%$ MT, left DLPFC rTMS in 68 patients with treatment-resistant depression and found a response rate of $31 \%$ for active rTMS compared with $6 \%$ for sham rTMS; remission rates were $20 \%$ for active rTMS and $3 \%$ for sham rTMS. ${ }^{159}$

Additional evidence for the clinical efficacy of fast rTMS to the left DLPFC comes from several favorable comparisons with ECT. ${ }^{160-163}$ Although one of these studies showed ECT to be superior to rTMS in treating patients with psychotic depression, ${ }^{160}$ these studies showed no statistically significant difference in antidepressant response between rTMS and ECT in nonpsychotic depressed patients. All studies used more than 10 treatment sessions and stimulated at $100 \%$ MT or greater. Importantly, these studies were not powered to demonstrate statistical equivalence between the two treatments, did not include a sham rTMS comparison, and did not consistently use the most aggressive ECT parameters. However, they still suggest that rTMS may possess antidepressant effects similar to ECT in some patients.

Other forms of rTMS have also shown evidence of antidepressant efficacy. Slow rTMS applied to the right DLPFC had antidepressant effects in several open ${ }^{164-167}$ and controlled studies. ${ }^{167-169}$ Low-frequency, left DLPFC rTMS has shown efficacy in a few small controlled studies. ${ }^{170-172}$ Other investigators have explored combinations of various rTMS parameters with mixed results. ${ }^{173-175}$

Studies of rTMS have shown it to be safe and well tolerated. ${ }^{152}$ Despite extensive neuropsychological testing, rTMS has consistently proven to have no negative cognitive side effects. ${ }^{176,177}$ Transient auditory threshold increases have been reported with TTMS $^{176}$; this can be eliminated with the use of foam earplugs. Some patients report a mild headache during and/or after rTMS, but this is typically short-lived and easily treated with over-thecounter analgesics. The most concerning risk of rTMS is a generalized seizure, although this risk appears to be greatly attenuated when established safety guidelines are followed. ${ }^{178}$

Despite its initial rationale and some preliminary supporting data, the mechanism of action of rTMS remains largely unknown. Imaging data have resulted in a mixed picture of the cortical excitatory effects of fast and slow rTMS at the prefrontal cortex, ${ }^{179-185}$ calling into question the "activation" of the DLPFC hypothesis for fast rTMS antidepressant effects. However, these same data 
also suggest rTMS can modulate the function of brain regions distant from the initial site of stimulation (DLPFC) but still implicated in the treatment of depression. Preclinical studies suggest rTMS may induce physiological and behavioral effects in animals similar to those elicited with established antidepressant treatments. ${ }^{186,187}$ Other data suggest frontally applied rTMS may induce dopamine release in subcortical structures $^{188-193}$ and may alter function within other monoamine systems. ${ }^{194}$

rTMS is therefore a potentially useful treatment for depression that requires further study to clarify the magnitude of clinical effects and its mechanism of action. It is generally safe and well tolerated and may eventually offer a noninvasive alternative to medications and other somatic treatments for depression, such as VNS and ECT. Two large, multisite studies of fast rTMS of the left DLPFC for treatment-resistant depression are currently ongoing and should produce relatively definitive results within the next $2-5$ years.

\section{Magnetic seizure therapy}

MST uses a modified rTMS system to induce a generalized seizure similar to that obtained with ECT. Available data suggest that the significant cognitive side effects associated with ECT may be minimize by electrode placement selection. ${ }^{41,42}$ Given this, the hope with MST is that by inducing a generalized seizure with very focal electrical stimulation of the prefrontal cortex, treatment will still be efficacious (or at least as efficacious as more focal forms of ECT) with significantly fewer cognitive side effects. Although no definitive results have been reported, there is some evidence that MST results in antidepressant effects with fewer cognitive side effects than ECT. ${ }^{195,196}$ It remains unclear whether MST is more or less efficacious than nonconvulsive TMS.

\section{Deep brain stimulation}

With deep brain stimulation (DBS), a small electrical stimulator is implanted into a defined brain location, often a subcortical area, and connected to a programmable subcutaneous pulse generator. Bilateral DBS of the subthalamus or globus pallidus is a relatively new, but generally accepted treatment for refractory Parkinson's disease. ${ }^{197}$

Several lines of evidence support the investigation of DBS as a treatment for depression. First, DBS has been clearly associated with significant mood changes in patients with Parkinson's disease ${ }^{198,199}$; thus, direct modulation of mood with DBS is possible. Second, functional imaging studies clearly implicate certain deep brain regions in the pathophysiology of depression, such as the amygdala and anterior cingulate cortex..$^{200,201}$ Function in these regions could be directly modulated with DBS. Third, a small case series reported potential benefit from bilateral internal capsule DBS in patients with severe, treatment-resistant OCD. ${ }^{202}$

One challenge in using DBS to treat depression is choosing the stimulation location. As above, internal capsule DBS may have efficacy in treating OCD, but the efficacy of this stimulation site in treating depression has not been demonstrated. The only published study of DBS in treating depression used high-frequency stimulation bilaterally in the white matter adjacent to the subgenual cingulate cortex. ${ }^{203}$ In this study, four of six highly treatment-refractory patients (five had failed ECT) were responders at the 6-month study end-point. Three of these patients were in remission at 6 months, and one was very near remission. No significant adverse events were noted.

The mechanism of action of DBS is not known, although DBS most likely modulates function within discrete neural networks. ${ }^{204}$ As discussed above, depression has been associated with dysfunctional frontal corticalstriato-thalamic neural circuitry. Thus, DBS may help to restore normal neural network function by activating compensatory neural pathways or possibly by circumventing dysfunctional "nodes" in the network. In the above study of DBS in the subgenual cingulate white matter, response was associated with changes in regional blood flow in brain regions clearly implicated in the pathophysiology of depression (dorsolateral prefrontal cortex, subgenual cingulate, perigenual anterior cingulate, hypothalamus, brainstem). ${ }^{203}$ Whether these changes were achieved through inactivation of a dysfunctional node (subgenual cingulate) or activation of compensatory neural pathways is unclear.

Side effects of DBS surgery and treatment can include intracranial hemorrhage, delirium, mood changes (including depression and mania), and movement disorders. $^{205}$ It is important to recognize that these effects were observed in patients with Parkinson's disease treated with DBS. It is not yet clear what side effects may occur in non-Parkinsonian patients that undergo DBS surgery and long-term treatment-likely the potential for side effects will depend greatly on the precise stimulation site.

In summary, DBS is an innovative technique for directly altering the function of deep brain structures that has shown efficacy in treating treatment-resistant Parkinson's disease. A very preliminary open study in refractory depression of high-frequency DBS applied to bilateral white matter adjacent to the subgenual cingulate showed promising results with no significant adverse events.

\section{CONCLUSION}

Depression is a highly prevalent and disabling condition associated with significant morbidity and mortality. Currently, available treatments for depression are effec- 
tive, although a significant number of patients respond poorly even to the most aggressive treatments. Advances in the neurobiology of depression have suggested a number of novel targets for antidepressant treatment. Although preliminary, results suggest that both pharmacologic innovations (CRF antagonists, glucocorticoid receptor antagonists, substance $\mathrm{P}$ receptor antagonists, NMDA receptor antagonists, transdermal selegiline, "triple" reuptake inhibitors and augmentation with atypical antipsychotics) and focal brain stimulation (VNS, TMS, MST, and DBS) may be effective in the treatment of depression. Although more study is needed to clarify the benefit of these treatments, it is clear that further study of the neurobiology of depression remains important as a means of providing targets for innovative targets for antidepressant therapies.

Acknowledgments: This work was supported by the National Institutes of Health (NIH)/National Institute of Mental Health (P50 MH 058922, R01 MH 042088, and U19 MH 069056) (to C.B.N.) and by the Emory Mentored Clinical Research Scholars Program through a grant from NIH/National Center for Research Resources (K12 RR 017643) (to P.E.H.).

Disclosures: C.B.N. has received grants from the American Foundation for Suicide Prevention (AFSP); AstraZeneca; Bristol-Myers-Squibb; Forest Laboratories; Janssen Pharmaceutica; National Alliance for Research in Schizophrenia and Depression (NARSAD); National Institute of Mental Health (NIMH); Pfizer Pharmaceuticals; Stanley Foundation; National Alliance for the Mentally Ill (NAMI); and Wyeth-Ayerst. He is a consultant for Abbott Laboratories, Acadia Pharmaceuticals, Bristol-Myers-Squibb, Corcept, Cypress Biosciences, Cyberonics, Eli Lilly, Forest Laboratories, GlaxoSmithKline, Janssen Pharmaceutica, Otsuka, Pfizer Pharmaceuticals, Quintiles, and Wyeth-Ayerst. He is on the Speakers Bureau for Abbott Laboratories, GlaxoSmithKline, Janssen Pharmaceutica, and Pfizer Pharmaceuticals. He owns stock in Corcept, Cypress Biosciences, and Acadia Pharmaceuticals. He is on the Board of Directors for AFSP, American Psychiatric Institute for Research and Education (APIRE), George West Mental Health Foundation, Novadel Pharma, and National Foundation for Mental Health (NFMH). He has patents for "Method and devices for transdermal delivery of lithium (US 6375,990 B1)" and "Method to estimate serotonin and norepinephrine transporter occupancy after drug treatment using patient or animal serum (provisional filing April 2001)." He has equity in Reevax, BMC-JR LLC, and CeNeRx. P.E.H. has received grants from the American Federation for Aging Research (AFAR), Neuronetics, Inc., and the National Center for Research Resources.

\section{REFERENCES}

1. Kessler RC, Berglund P, Demler O, Jin R, Merikangas KR, Walters EE. Lifetime prevalence and age-of-onset distributions of DSM-IV disorders in the National Comorbidity Survey Replication. Arch Gen Psychiatry 62:593-602, 2005.

2. Murray CJL, Lopez AD, eds. The global burden of disease. Boston: Harvard University Press, 1996.

3. Fava M. Diagnosis and definition of treatment-resistant depression. Biol Psychiatry 53:649-659, 2003.

4. Keller MB, Lavori PW, Mueller TI, Endicott J, Coryell W, Hirschfeld RM, Shea T. Time to recovery, chronicity, and levels of psychopathology in major depression. A 5-year prospective follow-up of 431 subjects. Arch Gen Psychiatry 49:809-816, 1992.
5. Fink M. Convulsive therapy: a review of the first 55 years. $J$ Affect Disord 63:1-15, 2001.

6. Sackeim HA. The definition and meaning of treatment-resistant depression. J Clin Psychiatry 62 [Suppl 16]:10-17, 2001.

7. Roffman JL, Marci CD, Glick DM, Dougherty DD, Rauch SL. Neuroimaging and the functional neuroanatomy of psychotherapy. Psychol Med 35:1385-1398, 2005.

8. Goldapple K, Segal Z, Garson C, Lau M, Bieling P, Kennedy S, Mayberg H. Modulation of cortical-limbic pathways in major depression: treatment-specific effects of cognitive behavior therapy. Arch Gen Psychiatry 61:34-41, 2004.

9. Arroll B, Macgillivray S, Ogston S, Reid I, Sullivan F, Williams B, Crombie I. Efficacy and tolerability of tricyclic antidepressants and SSRIs compared with placebo for treatment of depression in primary care: a meta-analysis. Ann Fam Med 3:449-456, 2005.

10. Potter WZ, Manji HK, Rudorfer MV. Tricyclics and Tetracyclics. In: Textbook of psychopharmacology (Schatzberg AF, Nemeroff CB, eds), Ed 2, pp 199-218. Washington, DC: The American Psychiatric Press, Inc., 1998.

11. Krishnan KR, Monoamine oxidase inhibitors. In: Textbook of psychopharmacology (Schatzberg AF, Nemeroff CB, eds), Ed 2, pp 239-249. Washington, DC: The American Psychiatric Press, Inc., 1998.

12. Tollefson GD, Rosenbaum JF. Selective serotonin reuptake inhibitors. In: Textbook of psychopharmacology (Schatzberg AF, Nemeroff CB, eds), Ed 2, pp 219-238. Washington, DC: The American Psychiatric Press, Inc., 1998.

13. Thase ME, Entsuah AR, Rudolph RL. Remission rates during treatment with venlafaxine or selective serotonin reuptake inhibitors. Br J Psychiatry 178:234-241, 2001.

14. Allgulander C, Hackett D, Salinas E. Venlafaxine extended release (ER) in the treatment of generalised anxiety disorder: twenty-four-week placebo-controlled dose-ranging study. Br J Psychiatry 179:15-22, 2001.

15. Gelenberg AJ, Lydiard RB, Rudolph RL, Aguiar L, Haskins JT, Salinas E. Efficacy of venlafaxine extended-release capsules in nondepressed outpatients with generalized anxiety disorder: a 6-month randomized controlled trial. JAMA 283:3082-3088, 2000.

16. Entsuah R, Chitra R. A benefit-risk analysis of once-daily venlafaxine extended release (XR) and venlafaxine immediate release (IR) in outpatients with major depression. Psychopharmacol Bull 33:671-676, 1997.

17. Thase ME. Effects of venlafaxine on blood pressure: a metaanalysis of original data from 3744 depressed patients. J Clin Psychiatry 59:502-508, 1998.

18. Whyte IM, Dawson AH, Buckley NA. Relative toxicity of venlafaxine and selective serotonin reuptake inhibitors in overdose compared to tricyclic antidepressants. QJM 96:369-374, 2003.

19. Buckley NA, McManus PR. Fatal toxicity of serotoninergic and other antidepressant drugs: analysis of United Kingdom mortality data. BMJ 325:1332-1333, 2002.

20. Davidson J, Watkins L, Owens M, Krulewicz S, Connor K, Carpenter D, Krishnan R, Nemeroff C. Effects of Paroxetine and Venlafaxine XR on heart rate variability in depression. J Clin Psychopharmacol 25:480-484, 2005.

21. Detke MJ, Wiltse CG, Mallinckrodt CH, McNamara RK, Demitrack MA, Bitter I. Duloxetine in the acute and long-term treatment of major depressive disorder: a placebo- and paroxetinecontrolled trial. Eur Neuropsychopharmacol 14:457-470, 2004.

22. Nelson JC, Wohlreich MM, Mallinckrodt CH, Detke MJ, Watkin JG, Kennedy JS. Duloxetine for the treatment of major depressive disorder in older patients. Am J Geriatr Psychiatry 13:227-235, 2005.

23. Thase ME, Haight BR, Richard N, Rockett CB, Mitton M, Modell JG, Vanmeter S, Harriett AE, Wang Y. Remission rates following antidepressant therapy with bupropion or selective serotonin reuptake inhibitors: a meta-analysis of original data from 7 randomized controlled trials. J Clin Psychiatry 66:974-981, 2005.

24. Zisook S, Rush AJ, Haight BR, Clines DC, Rockett CB. Use of Bupropion in combination with serotonin reuptake inhibitors. Biol Psychiatry, 13 Sep 2005.

25. Fawcett J, Barkin RL. A meta-analysis of eight randomized, 
double-blind, controlled clinical trials of mirtazapine for the treatment of patients with major depression and symptoms of anxiety. J Clin Psychiatry 59:123-127, 1998.

26. Owens MJ, Ieni JR, Knight DL, Winders K, Nemeroff CB. The serotonergic antidepressant nefazodone inhibits the serotonin transporter: in vivo and ex vivo studies. Life Sci 57:PL373PL380, 1995.

27. Owens MJ, Morgan WN, Plott SJ, Nemeroff CB. Neurotransmitter receptor and transporter binding profile of antidepressants and their metabolites. J Pharmacol Exp Ther 283:1305-1322, 1997.

28. Keller MB, McCullough JP, Klein DN, Arnow B, Dunner DL, Gelenberg AJ, Markowitz JC, Nemeroff CB, Russell JM, Thase ME, Trivedi MH, Zajecka J. A comparison of nefazodone, the cognitive behavioral-analysis system of psychotherapy, and their combination for the treatment of chronic depression. $N$ Engl $J$ Med 342:1462-1470, 2000.

29. Aranda-Michel J, Koehler A, Bejarano PA, Poulos JE, Luxon BA, Khan CM, Ee LC, Balistreri WF, Weber FL Jr. Nefazodoneinduced liver failure: report of three cases. Ann Intern Med 130 [4 Pt 1]:285-288, 1999.

30. Mendelson WB. A review of the evidence for the efficacy and safety of trazodone in insomnia. J Clin Psychiatry 66:469-476, 2005.

31. UK ECT Review Group. Efficacy and safety of electroconvulsive therapy in depressive disorders: a systematic review and metaanalysis. Lancet 361:799-808, 2003.

32. American Psychiatric Association. Practice guideline for the treatment of patients with major depressive disorder (revision). Am J Psychiatry 157 [4 Suppl]:1-45, 2000.

33. Avery D, Winokur G. The efficacy of electroconvulsive therapy and antidepressants in depression. Biol Psychiatry 12:507-523, 1977.

34. Avery D, Winokur G. Suicide, attempted suicide, and relapse rates in depression. Arch Gen Psychiatry 35:749-753, 1978.

35. Avery D, Lubrano A. Depression treated with imipramine and ECT: the DeCarolis study reconsidered. Am J Psychiatry 136: 559-562, 1979.

36. Prudic J, Haskett RF, Mulsant B, Malone KM, Pettinati HM, Stephens S, Greenberg R, Rifas SL, Sackeim HA. Resistance to antidepressant medications and short-term clinical response to ECT. Am J Psychiatry 153:985-992, 1996.

37. Avery D, Winokur G. Mortal in depressed patients treated with electroconvulsive therapy and antidepressants. Arch Gen Psychiatry 33:1029-1037, 1976.

38. Rose D, Fleischmann P, Wykes T, Leese M, Bindman J Patients' perspectives on electroconvulsive therapy: systematic review. BMJ 326:1363, 2003.

39. Zielinski RJ, Roose SP, Devanand DP, Woodring S, Sackeim HA. Cardiovascular complications of ECT in depressed patients with cardiac disease. Am J Psychiatry 150:904-909, 1993.

40. Sackeim HA, Ross FR, Hopkins N, Calev L, Devanand DP. Subjective side effects acutely following ECT: associations with treatment modality and clinical response. Convuls Ther 3:100$110,1987$.

41. Bakewell CJ, Russo J, Tanner C, Avery DH, Neumaier JF. Comparison of clinical efficacy and side effects for bitemporal and bifrontal electrode placement in electroconvulsive therapy. J ECT 20:145-153, 2004.

42. Sackeim HA, Prudic J, Devanand DP, Nobler MS, Lisanby SH, Peyser S, Fitzsimons L, Moody BJ, Clark J. A prospective, randomized, double-blind comparison of bilateral and right unilateral electroconvulsive therapy at different stimulus intensities. Arch Gen Psychiatry 57:425-434, 2000.

43. Sackeim HA, Haskett RF, Mulsant BH, Thase ME, Mann JJ, Pettinati HM, Greenberg RM, Crowe RR, Cooper TB, Prudic J. Continuation pharmacotherapy in the prevention of relapse following electroconvulsive therapy: a randomized controlled trial. JAMA 285:1299-1307, 2001.

44. Nemeroff CB, Bissette G, Akil H, Fink M. Neuropeptide concentrations in the cerebrospinal fluid of depressed patients treated with electroconvulsive therapy. Corticotrophin-releasing factor, $\beta$-endorphin and somatostatin. Br J Psychiatry 158:59-63, 1991.

45. Wahlund B, von Rosen D. ECT of major depressed patients in relation to biological and clinical variables: a brief overview. Neuropsychopharmacology 28 [Suppl 1]:S21-S26, 2003.

46. Sackeim HA, Decina P, Prohovnik I, Malitz S, Resor SR. Anticonvulsant and antidepressant properties of electroconvulsive therapy: a proposed mechanism of action. Biol Psychiatry 18: 1301-1310, 1983.

47. Gutman DA, Owens MJ, Nemeroff CB. Corticotropin-releasing factor receptor and glucocorticoid receptor antagonists: new approaches to antidepressant treatment. In: Current and future developments in psychopharmacology (Den Boer JA, George MS, ter Horst GJ, eds). Amsterdam: Benecke, N.I., in press.

48. Arborelius L, Owens MJ, Plotsky PM, Nemeroff CB. The role of corticotropin-releasing factor in depression and anxiety disorders. J Endocrinol 160:1-12, 1999.

49. Veith RC, Lewis N, Langohr JI, Murburg MM, Ashleigh EA, Castillo S, Peskind ER, Pascualy M, Bissette G, Nemeroff CB, et al. Effect of desipramine on cerebrospinal fluid concentrations of corticotropin-releasing factor in human subjects. Psychiatry Res 46:1-8, 1993.

50. Zobel AW, Nickel T, Kunzel HE, Ackl N, Sonntag A, Ising M, Holsboer F. Effects of the high-affinity corticotropin-releasing hormone receptor 1 antagonist R121919 in major depression: the first 20 patients treated. J Psychiatr Res 34:171-181, 2000.

51. Wolkowitz OM, Reus VI. Treatment of depression with antiglucocorticoid drugs. Psychosom Med 61:698-711, 1999.

52. Murphy BE, Filipini D, Ghadirian AM. Possible use of glucocorticoid receptor antagonists in the treatment of major depression: preliminary results using RU 486. J Psychiatry Neurosci 18:209213, 1993.

53. Belanoff JK, Kalehzan M, Sund B, Fleming Ficek SK, Schatzberg AF. Cortisol activity and cognitive changes in psychotic major depression. Am J Psychiatry 158:1612-1616, 2001.

54. Belanoff JK, Flores BH, Kalezhan M, Sund B, Schatzberg AF. Rapid reversal of psychotic depression using mifepristone. J Clin Psychopharmacol 21:516-521, 2001.

55. Belanoff JK, Rothschild AJ, Cassidy F, DeBattista C, Baulieu EE, Schold C, Schatzberg AF. An open label trial of C-1073 (mifepristone) for psychotic major depression. Biol Psychiatry 52: 386-392, 2002.

56. Ku YH, Tan L, Li LS, Ding X. Role of corticotropin-releasing factor and substance $\mathrm{P}$ in pressor responses of nuclei controlling emotion and stress. Peptides 19:677-682, 1998.

57. Bittencourt JC, Benoit R, Sawchenko PE. Distribution and origins of substance P-immunoreactive projections to the paraventricular and supraoptic nuclei: partial overlap with ascending catecholaminergic projections. J Chem Neuroanat 4:63-78, 1991.

58. Magoul R, Dubourg P, Benjelloun W, Tramu G. Synaptic inputs of tachykinin-containing nerve terminals to target tyrosine-hydroxylase-, $\beta$-endorphin- and neuropeptide Y-producing neurons of the arcuate nucleus. Double pre-embedding immunocytochemical study in the rat. J Chem Neuroanat 6:419-429, 1993.

59. Pelletier G, Steinbusch HW, Verhofstad AA. Immunoreactive substance $\mathrm{P}$ and serotonin present in the same dense-core vesicles. Nature 293:71-72, 1981.

60. Helke CJ, Yang L. Interactions and coexistence of neuropeptides and serotonin in spinal autonomic systems. Ann NY Acad Sci 780:185-192, 1996.

61. Culman J, Unger T. Central tachykinins: mediators of defence reaction and stress reactions. Can J Physiol (Lond) Pharmacol 73:885-891, 1995.

62. Helke CJ, Krause JE, Mantyh PW, Couture R, Bannon MJ. Diversity in mammalian tachykinin peptidergic neurons: multiple peptides, receptors, and regulatory mechanisms. FASEB J 4:1606-1615, 1990.

63. Kramer MS, Cutler N, Feighner J, Shrivastava R, Carman J, Sramek JJ, Reines SA, Liu G, Snavely D, Wyatt-Knowles E, Hale JJ, Mills SG, MacCoss M, Swain CJ, Harrison T, Hill RG, Hefti F, Scolnick EM, Cascieri MA, Chicchi GG, Sadowski S, Williams AR, Hewson L, Smith D, Carlson EJ, Hargreaves RJ, Rupniak NM. Distinct mechanism for antidepressant activity by blockade of central substance P receptors. Science 281:1640$1645,1998$.

64. Culman J, Klee S, Ohlendorf C, Unger T. Effect of tachykinin 
receptor inhibition in the brain on cardiovascular and behavioral responses to stress. J Pharmacol Exp Ther 280:238-246, 1997.

65. Rimon R, Le Greves P, Nyberg F, Heikkila L, Salmela L, Terenius L. Elevation of substance P-like peptides in the CSF of psychiatric patients. Biol Psychiatry 19:509-516, 1984.

66. Bondy B, Baghai TC, Minov C, Schule C, Schwarz MJ, Zwanzger P, Rupprecht R, Moller HJ. Substance P serum levels are increased in major depression: preliminary results. Biol Psychiatry 53:538-542, 2003.

67. Berrettini WH, Rubinow DR, Nurnberger JI Jr, Simmons-Alling S, Post RM, Gershon ES. CSF substance P immunoreactivity in affective disorders. Biol Psychiatry 20:965-970, 1985.

68. Krishnan KR. Clinical experience with substance P receptor (NK1) antagonists in depression. J Clin Psychiatry 63 [Suppl 11]:25-29, 2002.

69. Kramer MS, Winokur A, Kelsey J, Preskorn SH, Rothschild AJ, Snavely D, Ghosh K, Ball WA, Reines SA, Munjack D, Apter JT, Cunningham L, Kling M, Bari M, Getson A, Lee Y. Demonstration of the efficacy and safety of a novel substance P (NK1) receptor antagonist in major depression. Neuropsychopharmacology 29:385-392, 2004.

70. Herpfer I, Lieb K. Substance P receptor antagonists in psychiatry: rationale for development and therapeutic potential. CNS Drugs 19:275-293, 2005.

71. Paul IA, Skolnick P. Glutamate and depression: clinical and preclinical studies. Ann NY Acad Sci 1003:250-272, 2003.

72. Zarate CA Jr, Du J, Quiroz J, Gray NA, Denicoff KD, Singh J, Charney DS, Manji HK. Regulation of cellular plasticity cascades in the pathophysiology and treatment of mood disorders: role of the glutamatergic system. Ann NY Acad Sci 1003:273-291, 2003.

73. McEwen BS. Stress and hippocampal plasticity. Аnпи Rev Neurosci 22:105-122, 1999.

74. Sapolsky RM. The possibility of neurotoxicity in the hippocampus in major depression: a primer on neuron death. Biol Psychiatry 48:755-765, 2000.

75. Rogoz Z, Skuza G, Maj J, Danysz W. Synergistic effect of uncompetitive NMDA receptor antagonists and antidepressant drugs in the forced swimming test in rats. Neuropharmacology 42:1024-1030, 2002.

76. Rogoz Z, Skuza G, Kusmider M, Wojcikowski J, Kot M, Daniel WA. Synergistic effect of imipramine and amantadine in the forced swimming test in rats. Behavioral and pharmacokinetic studies. Pol J Pharmacol 56:179-185, 2004.

77. Palucha A, Branski P, Szewczyk B, Wieronska JM, Klak K, Pilc A. Potential antidepressant-like effect of MTEP, a potent and highly selective mGluR5 antagonist. Pharmacol Biochem Behav 81:901-906, 2005.

78. Pilc A, Klodzinska A, Branski P, Nowak G, Palucha A, Szewczyk B, Tatarczynska E, Chojnacka-Wojcik E, Wieronska JM. Multiple MPEP administrations evoke anxiolytic- and antidepressantlike effects in rats. Neuropharmacology 43:181-187, 2002.

79. Li X, Witkin JM, Need AB, Skolnick P. Enhancement of antidepressant potency by a potentiator of AMPA receptors. Cell Mol Neurobiol 23:419-430, 2003.

80. Zarate CA Jr, Payne JL, Quiroz J, Sporn J, Denicoff KK, Luckenbaugh D, Charney DS, Manji HK. An open-label trial of riluzole in patients with treatment-resistant major depression. Am J Psychiatry 161:171-174, 2004.

81. Zarate CA Jr, Quiroz JA, Singh JB, Denicoff KD, De Jesus G, Luckenbaugh DA, Charney DS, Manji HK. An open-label trial of the glutamate-modulating agent riluzole in combination with lithium for the treatment of bipolar depression. Biol Psychiatry 57: 430-432, 2005.

82. Stryjer R, Strous RD, Shaked G, Bar F, Feldman B, Kotler M, Polak L, Rosenzcwaig S, Weizman A. Amantadine as augmentation therapy in the management of treatment-resistant depression. Int Clin Psychopharmacol 18:93-96, 2003.

83. Mann JJ, Aarons SF, Wilner PJ, Keilp JG, Sweeney JA, Pearlstein T, Frances AJ, Kocsis JH, Brown RP. A controlled study of the antidepressant efficacy and side effects of (-)-deprenyl. A selective monoamine oxidase inhibitor. Arch Gen Psychiatry 46: 45-50, 1989.

84. Wecker L, James S, Copeland N, Pacheco MA. Transdermal selegiline: targeted effects on monoamine oxidases in the brain. Biol Psychiatry 54:1099-1104, 2003.

85. Amsterdam JD. A double-blind, placebo-controlled trial of the safety and efficacy of selegiline transdermal system without dietary restrictions in patients with major depressive disorder. J Clin Psychiatry 64:208-214, 2003.

86. Bodkin JA, Amsterdam JD. Transdermal selegiline in major depression: a double-blind, placebo-controlled, parallel-group study in outpatients. Am J Psychiatry 159:1869-1875, 2002.

87. Dailly E, Chenu F, Renard CE, Bourin M. Dopamine, depression and antidepressants. Fundam Clin Pharmacol 18:601-607, 2004.

88. Elhwuegi AS. Central monoamines and their role in major depression. Prog Neuropsychopharmacol Biol Psychiatry 28:435451, 2004.

89. Pania L, Gessab GL. Dopaminergic deficit and mood disorders. Int Clin Psychopharmacol 17 [Suppl 4]:S1-S7 [discussion S7], 2002.

90. Nierenberg AA, Dougherty D, Rosenbaum JF. Dopaminergic agents and stimulants as antidepressant augmentation strategies. J Clin Psychiatry 59 [Suppl 5]:60-63 [discussion 64], 1998.

91. Skolnick P, Popik P, Janowsky A, Beer B, Lippa AS. Antidepressant-like actions of DOV 21,947: a "triple" reuptake inhibitor. Eur J Pharmacol 461:99-104, 2003.

92. Skolnick P, Popik P, Janowsky A, Beer B, Lippa AS. "Broad spectrum" antidepressants: is more better for the treatment of depression? Life Sci 73:3175-3179, 2003.

93. Beer B, Stark J, Krieter P, Czobor P, Beer G, Lippa A, Skolnick P. DOV 216,303, a "triple" reuptake inhibitor: safety, tolerability, and pharmacokinetic profile. J Clin Pharmacol 44:1360-1367, 2004.

94. Fava M. Augmentation and combination strategies in treatmentresistant depression. J Clin Psychiatry 62 [Suppl 18]:4-11, 2001.

95. DeBattista C, Solvason HB, Poirier J, Kendrick E, Schatzberg AF. A prospective trial of bupropion SR augmentation of partial and non-responders to serotonergic antidepressants. J Clin Psychopharmacol 23:27-30, 2003.

96. Nemeroff CB. Augmentation strategies in patients with refractory depression. Depress Anxiety 4:169-181, 1996.

97. Joffe RT. The use of thyroid supplements to augment antidepressant medication. J Clin Psychiatry 59 [Suppl 5]:26-29 [discussion 30-31], 1998.

98. Kapur S, Remington G. Atypical antipsychotics: new directions and new challenges in the treatment of schizophrenia. Annu Rev Med 52:503-517, 2001.

99. Meltzer HY. The mechanism of action of novel antipsychotic drugs. Schizophr Bull 17:263-287, 1991.

100. Meyer JM. A retrospective comparison of weight, lipid, and glucose changes between risperidone- and olanzapine-treated inpatients: metabolic outcomes after 1 year. J Clin Psychiatry 63: 425-433, 2002.

101. Blasi G, Bertolino A. Imaging genomics and response to treatment with antipsychotics in schizophrenia. NeuroRx 3:117-130, 2006.

102. Berk M, Dodd S. Efficacy of atypical antipsychotics in bipolar disorder. Drugs 65:257-269, 2005.

103. Bystritsky A, Ackerman DL, Rosen RM, Vapnik T, Gorbis E, Maidment KM, Saxena S. Augmentation of serotonin reuptake inhibitors in refractory obsessive-compulsive disorder using adjunctive olanzapine: a placebo-controlled trial. J Clin Psychiatry 65:565-568, 2004.

104. Connor KM, Payne VM, Gadde KM, Zhang W, Davidson JR. The use of aripiprazole in obsessive-compulsive disorder: preliminary observations in 8 patients. J Clin Psychiatry 66:49-51, 2005.

105. Bogan AM, Koran LM, Chuong HW, Vapnik T, Bystritsky A. Quetiapine augmentation in obsessive-compulsive disorder resistant to serotonin reuptake inhibitors: an open-label study. J Clin Psychiatry 66:73-79, 2005.

106. Hamner MB, Deitsch SE, Brodrick PS, Ulmer HG, Lorberbaum JP. Quetiapine treatment in patients with posttraumatic stress disorder: an open trial of adjunctive therapy. J Clin Psychopharmacol 23:15-20, 2003. 
107. Bartzokis G, Lu PH, Turner J, Mintz J, Saunders CS. Adjunctive risperidone in the treatment of chronic combat-related posttraumatic stress disorder. Biol Psychiatry 57:474-479, 2005.

108. Stein MB, Kline NA, Matloff JL. Adjunctive olanzapine for SSRI-resistant combat-related PTSD: a double-blind, placebocontrolled study. Am J Psychiatry 159:1777-1779, 2002.

109. Thase ME. What role do atypical antipsychotic drugs have in treatment-resistant depression? J Clin Psychiatry 63:95-103, 2002.

110. Worthington JJ 3rd, Kinrys G, Wygant LE, Pollack MH. Aripiprazole as an augmentor of selective serotonin reuptake inhibitors in depression and anxiety disorder patients. Int Clin Psychopharmacol 20:9-11, 2005.

111. Papakostas GI, Petersen TJ, Nierenberg AA, Murakami JL, Alpert JE, Rosenbaum JF, Fava M. Ziprasidone augmentation of selective serotonin reuptake inhibitors (SSRIs) for SSRI-resistant major depressive disorder. J Clin Psychiatry 65:217-221, 2004.

112. Hirose S, Ashby CR Jr. An open pilot study combining risperidone and a selective serotonin reuptake inhibitor as initial antidepressant therapy. J Clin Psychiatry 63:733-736, 2002.

113. Stahl SM. Finding what you are not looking for: strategies for developing novel treatments in psychiatry. NeuroRx 3:3-9, 2006.

114. Mayberg HS. Positron emission tomography imaging in depression: a neural systems perspective. Neuroimaging Clin $N \mathrm{Am}$ 13:805-815, 2003.

115. Drevets WC, Raichle ME. Neuroanatomical circuits in depression: implications for treatment mechanisms. Psychopharmacol Bull 28:261-274, 1992.

116. Rauch SL. Neuroimaging and neurocircuitry models pertaining to the neurosurgical treatment of psychiatric disorders. Neurosurg Clin N Am 14:213-223, vii-viii, 2003.

117. Cosgrove GR, Rauch SL. Stereotactic cingulotomy. Neurosurg Clin N Am 14:225-235, 2003.

118. Greenberg BD, Price LH, Rauch SL, Friehs G, Noren G, Malone D, Carpenter LL, Rezai AR, Rasmussen SA. Neurosurgery for intractable obsessive-compulsive disorder and depression: critical issues. Neurosurg Clin N Am 14:199-212, 2003.

119. Carlson PJ, Singh JB, Zarate CA Jr, Drevets WC, Manji HK. Neural circuitry and neuroplasticity in mood disorders: insights for novel therapeutic targets. NeuroRx 3:22-41, 2006.

120. Matthews K, Eljamel MS. Status of neurosurgery for mental disorder in Scotland. Selective literature review and overview of current clinical activity. Br J Psychiatry 182:404-411, 2003.

121. Ben-Menachem E. Vagus nerve stimulation, side effects, and long-term safety. J Clin Neurophysiol 18:415-418, 2001.

122. Ben-Menachem E. Vagus-nerve stimulation for the treatment of epilepsy. Lancet Neurol 1:477-482, 2002.

123. George MS, Rush AJ, Sackeim HA, Marangell LB. Vagus nerve stimulation (VNS): utility in neuropsychiatric disorders. Int J Neuropsychopharmacol 6:73-83, 2003.

124. Sackeim HA. The anticonvulsant hypothesis of the mechanisms of action of ECT: current status. J ECT 15:5-26, 1999.

125. Harden CL, Pulver MC, Ravdin LD, Nikolov B, Halper JP, Labar DR. A pilot study of mood in epilepsy patients treated with vagus nerve stimulation. Epilepsy Behav 1:93-99, 2000.

126. Elger G, Hoppe C, Falkai P, Rush AJ, Elger CE. Vagus nerve stimulation is associated with mood improvements in epilepsy patients. Epilepsy Res 42:203-210, 2000.

127. Sackeim HA, Rush AJ, George MS, Marangell LB, Husain MM, Nahas Z, Johnson CR, Seidman S, Giller C, Haines S, Simpson RK Jr, Goodman RR. Vagus nerve stimulation (VNS) for treatment-resistant depression: efficacy, side effects, and predictors of outcome. Neuropsychopharmacology 25:713-728, 2001.

128. Marangell LB, Rush AJ, George MS, Sackeim HA, Johnson CR, Husain MM, Nahas Z, Lisanby SH. Vagus nerve stimulation (VNS) for major depressive episodes: one year outcomes. Biol Psychiatry 51:280-287, 2002.

129. Nahas Z, Marangell LB, Husain MM, Rush AJ, Sackeim HA, Lisanby SH, Martinez JM, George MS. Two-Year Outcome of Vagus Nerve Stimulation (VNS) for Treatment of Major Depressive Episodes. J Clin Psychiatry 66:1097-1104, 2005.

130. Rush AJ, Marangell LB, Sackeim HA, George MS, Brannan SK, Davis SM, Howland R, Kling MA, Rittberg BR, Burke WJ,
Rapaport MH, Zajecka J, Nierenberg AA, Husain MM, Ginsberg D, Cooke RG. Vagus nerve stimulation for treatment-resistant depression: a randomized, controlled acute phase trial. Biol Psychiatry 58:347-354, 2005.

131. Rush AJ, Sackeim HA, Marangell LB, George MS, Brannan SK, Davis SM, Lavori P, Howland R, Kling MA, Rittberg B, Carpenter L, Ninan P, Moreno F, Schwartz T, Conway C, Burke M, Barry JJ. Effects of 12 months of vagus nerve stimulation in treatment-resistant depression: a naturalistic study. Biol Psychiatry 58:355-363, 2005.

132. George MS, Rush AJ, Marangell LB, Sackeim HA, Brannan SK, Davis SM, Howland R, Kling MA, Moreno F, Rittberg B, Dunner D, Schwartz T, Carpenter L, Burke M, Ninan P, Goodnick P. A one-year comparison of vagus nerve stimulation with treatment as usual for treatment-resistant depression. Biol Psychiatry 58:364$373,2005$.

133. Chae JH, Nahas Z, Lomarev M, Denslow S, Lorberbaum JP, Bohning DE, George MS. A review of functional neuroimaging studies of vagus nerve stimulation (VNS). J Psychiatr Res 37: 443-455, 2003.

134. Ben-Menachem E, Hamberger A, Hedner T, Hammond EJ, Uthman BM, Slater J, Treig T, Stefan H, Ramsay RE, Wernicke JF, et al. Effects of vagus nerve stimulation on amino acids and other metabolites in the CSF of patients with partial seizures. Epilepsy Res 20:221-227, 1995.

135. Marrosu F, Serra A, Maleci A, Puligheddu M, Biggio G, Piga M. Correlation between $\mathrm{GABA}(\mathrm{A})$ receptor density and vagus nerve stimulation in individuals with drug-resistant partial epilepsy. Epilepsy Res 55:59-70, 2003.

136. Carpenter LL, Moreno FA, Kling MA, Anderson GM, Regenold WT, Labiner DM, Price LH. Effect of vagus nerve stimulation on cerebrospinal fluid monoamine metabolites, norepinephrine, and $\gamma$-aminobutyric acid concentrations in depressed patients. Biol Psychiatry 56:418-426, 2004.

137. Groves DA, Bowman EM, Brown VJ. Recordings from the rat locus coeruleus during acute vagal nerve stimulation in the anaesthetised rat. Neurosci Lett 379:174-179, 2005.

138. Lechner SM, Curtis AL, Brons R, Valentino RJ. Locus coeruleus activation by colon distention: role of corticotropin-releasing factor and excitatory amino acids. Brain Res 756:114-124, 1997.

139. Hassert DL, Miyashita T, Williams CL. The effects of peripheral vagal nerve stimulation at a memory-modulating intensity on norepinephrine output in the basolateral amygdala. Behav Neurosci 118:79-88, 2004.

140. Krahl SE, Clark KB, Smith DC, Browning RA. Locus coeruleus lesions suppress the seizure-attenuating effects of vagus nerve stimulation. Epilepsia 39:709-714, 1998.

141. Anand S, Hotson J. Transcranial magnetic stimulation: Neurophysiological applications and safety. Brain Cogn 50:366-386, 2002.

142. Pascual-Leone A, Valls-Sole J, Wassermann EM, Hallett M. Responses to rapid-rate transcranial magnetic stimulation of the human motor cortex. Brain 117 [Pt 4]:847-858, 1994.

143. Chen R, Classen J, Gerloff C, Celnik P, Wassermann EM, Hallett M, Cohen LG. Depression of motor cortex excitability by lowfrequency transcranial magnetic stimulation. Neurology 48:1398-1403, 1997.

144. George M, Ketter T, Post R. Prefrontal cortex dysfunction in clinical depression. Depression 2:59-72, 1994.

145. Bench CJ, Friston KJ, Brown RG, Scott LC, Frackowiak RS, Dolan RJ. The anatomy of melancholia-focal abnormalities of cerebral blood flow in major depression. Psychol Med 22:607615, 1992.

146. Biver F, Goldman S, Delvenne V, Luxen A, De Maertelaer V, Hubain P, Mendlewicz J, Lotstra F. Frontal and parietal metabolic disturbances in unipolar depression. Biol Psychiatry 36:381-388, 1994.

147. George MS, Wassermann EM, Williams WA, Callahan A, Ketter TA, Basser P, Hallett M, Post RM. Daily repetitive transcranial magnetic stimulation (rTMS) improves mood in depression. Neuroreport 6:1853-1856, 1995.

148. George MS, Wassermann EM, Williams WA, Steppel J, PascualLeone A, Basser P, Hallett M, Post RM. Changes in mood and 
hormone levels after rapid-rate transcranial magnetic stimulation (rTMS) of the prefrontal cortex. J Neuropsychiatry Clin Neurosci 8:172-180, 1996.

149. Fleischmann A, Prolov K, Abarbanel J, Belmaker RH. The effect of transcranial magnetic stimulation of rat brain on behavioral models of depression. Brain Res 699:130-132, 1995.

150. Burt T, Lisanby SH, Sackeim HA. Neuropsychiatric applications of transcranial magnetic stimulation: a meta-analysis. Int J Neuropsychopharmacol 5:73-103, 2002.

151. Epstein C, Figiel G, McDonald W, Amazon-Leece J, Figiel L. Rapid rate transcranial magnetic stimulation in young and middle-aged refractory depressed patients. Psychiatr Ann 28:36-39, 1998.

152. Holtzheimer PE 3rd, Russo J, Avery DH. A meta-analysis of repetitive transcranial magnetic stimulation in the treatment of depression. Psychopharmacol Bull [Erratum 2037:2005, 2003] 35:149-169, 2001.

153. Kozel FA, George MS. Meta-analysis of left prefrontal repetitive transcranial magnetic stimulation (rTMS) to treat depression. J Psychiatr Pract 8:270-275, 2002.

154. Martin JL, Barbanoj MJ, Schlaepfer TE, Thompson E, Perez V, Kulisevsky J. Repetitive transcranial magnetic stimulation for the treatment of depression: systematic review and meta-analysis. Br J Psychiatry 182:480-491, 2003.

155. Schlaepfer TE, Kosel M, Nemeroff CB. Efficacy of repetitive transcranial magnetic stimulation (rTMS) in the treatment of affective disorders. Neuropsychopharmacology 28:201-205, 2003.

156. Entsuah AR, Huang H, Thase ME. Response and remission rates in different subpopulations with major depressive disorder administered venlafaxine, selective serotonin reuptake inhibitors, or placebo. J Clin Psychiatry 62:869-877, 2001.

157. Gershon AA, Dannon PN, Grunhaus L. Transcranial magnetic stimulation in the treatment of depression. Am J Psychiatry 160: 835-845, 2003.

158. Holtzheimer PE 3rd, Russo J, Claypoole KH, Roy-Byrne P, Avery DH. Shorter duration of depressive episode may predict response to repetitive transcranial magnetic stimulation. Depress Anxiety 19:24-30, 2004.

159. Avery DH, Holtzheimer III PE, Fawaz W, Russo J, Neumaier J, Dunner DL, Haynor DR, Claypoole KH, Wajdik C, Roy-Byrne P. A controlled study of repetitive transcranial magnetic stimulation in medication-resistant major depression. Biol Psychiatry, $31 \mathrm{Au}-$ gust 2005.

160. Grunhaus L, Dannon PN, Schreiber S, Dolberg OH, Amiaz R, Ziv $\mathrm{R}$, Lefkifker E. Repetitive transcranial magnetic stimulation is as effective as electroconvulsive therapy in the treatment of nondelusional major depressive disorder: an open study. Biol Psychiatry 47:314-324, 2000.

161. Grunhaus L, Schreiber S, Dolberg OT, Polak D, Dannon PN. A randomized controlled comparison of electroconvulsive therapy and repetitive transcranial magnetic stimulation in severe and resistant nonpsychotic major depression. Biol Psychiatry 53:324331, 2003.

162. Janicak PG, Dowd SM, Martis B, Alam D, Beedle D, Krasuski J, Strong MJ, Sharma R, Rosen C, Viana M. Repetitive transcranial magnetic stimulation versus electroconvulsive therapy for major depression: preliminary results of a randomized trial. Biol Psychiatry 51:659-667, 2002.

163. Pridmore S, Bruno R, Turnier-Shea Y, Reid P, Rybak M. Comparison of unlimited numbers of rapid transcranial magnetic stimulation (rTMS) and ECT treatment sessions in major depressive episode. Int J Neuropsychopharmacol 3:129-134, 2000.

164. Feinsod M, Kreinin B, Chistyakov A, Klein E. Preliminary evidence for a beneficial effect of low-frequency, repetitive transcranial magnetic stimulation in patients with major depression and schizophrenia. Depress Anxiety 7:65-68, 1998.

165. Menkes DL, Bodnar P, Ballesteros RA, Swenson MR. Right frontal lobe slow frequency repetitive transcranial magnetic stimulation (SF r-TMS) is an effective treatment for depression: a case-control pilot study of safety and efficacy. J Neurol Neurosurg Psychiatry 67:113-115, 1999.

166. Brasil-Neto JP, Boechat-Barros R, da Mota-Silveira DA. [The use of slow-frequency transcranial magnetic stimulation in the treat- ment of depression at Brasilia University Hospital: preliminary findings]. Ar Qneuropsiquiatr 61:83-86, 2003.

167. Klein E, Kreinin I, Chistyakov A, Koren D, Mecz L, Marmur S, Ben-Shachar D, Feinsod M. Therapeutic efficacy of right prefrontal slow repetitive transcranial magnetic stimulation in major depression: a double-blind controlled study. Arch Gen Psychiatry 56:315-320, 1999.

168. Kauffmann CD, Cheema MA, Miller BE. Slow right prefrontal transcranial magnetic stimulation as a treatment for medicationresistant depression: a double-blind, placebo-controlled study. Depress Anxiety 19:59-62, 2004.

169. Fitzgerald PB, Brown TL, Marston NA, Daskalakis ZJ, De Castella A, Kulkarni J Transcranial magnetic stimulation in the treatment of depression: a double-blind, placebo-controlled trial. Arch Gen Psychiatry 60:1002-1008, 2003.

170. Padberg F, Zwanzger P, Thoma H, Kathmann N, Haag C, Greenberg BD, Hampel H, Moller HJ. Repetitive transcranial magnetic stimulation (rTMS) in pharmacotherapy-refractory major depression: comparative study of fast, slow and sham rTMS. Psychiatry Res 88:163-171, 1999.

171. Kimbrell TA, Little JT, Dunn RT, Frye MA, Greenberg BD, Wassermann EM, Repella JD, Danielson AL, Willis MW, Benson BE, Speer AM, Osuch E, George MS, Post RM. Frequency dependence of antidepressant response to left prefrontal repetitive transcranial magnetic stimulation (rTMS) as a function of baseline cerebral glucose metabolism. Biol Psychiatry 46:1603-1613, 1999.

172. Rosenberg PB, Mehndiratta RB, Mehndiratta YP, Wamer A, Rosse RB, Balish M. Repetitive transcranial magnetic stimulation treatment of comorbid posttraumatic stress disorder and major depression. J Neuropsychiatry Clin Neurosci 14:270-276, 2002.

173. Loo CK, Mitchell PB, Croker VM, Malhi GS, Wen W, Gandevia SC, Sachdev PS. Double-blind controlled investigation of bilateral prefrontal transcranial magnetic stimulation for the treatment of resistant major depression. Psychol Med 33:33-40, 2003.

174. Hausmann A, Kemmler G, Walpoth M, Mechtcheriakov S, Kramer-Reinstadler K, Lechner T, Walch T, Deisenhammer EA, Kofler M, Rupp CI, Hinterhuber H, Conca A. No benefit derived from repetitive transcranial magnetic stimulation in depression: a prospective, single centre, randomised, double blind, sham controlled "add on" trial. J Neurol Neurosurg Psychiatry 75:320322, 2004.

175. Conca A, Di Pauli J, Beraus W, Hausmann A, Peschina W, Schneider H, Konig P, Hinterhuber H. Combining high and low frequencies in rTMS antidepressive treatment: preliminary results. Hum Psychopharmacol 17:353-356, 2002.

176. Loo C, Sachdev P, Elsayed H, McDarmont B, Mitchell P, Wilkinson M, Parker G, Gandevia S. Effects of a 2- to 4-week course of repetitive transcranial magnetic stimulation (rTMS) on neuropsychologic functioning, electroencephalogram, and auditory threshold in depressed patients. Biol Psychiatry 49:615-623, 2001.

177. Martis B, Alam D, Dowd SM, Hill SK, Sharma RP, Rosen C, Pliskin N, Martin E, Carson V, Janicak PG. Neurocognitive effects of repetitive transcranial magnetic stimulation in severe major depression. Clin Neurophysiol 114:1125-1132, 2003.

178. Wassermann EM. Risk and safety of repetitive transcranial magnetic stimulation: report and suggested guidelines from the International Workshop on the Safety of Repetitive Transcranial Magnetic Stimulation, June 5-7, 1996. Electroencephalogr Clin Neurophysiol 108:1-16, 1998.

179. Speer AM, Kimbrell TA, Wassermann EM, J DR, Willis MW, Herscovitch P, Post RM. Opposite effects of high and low frequency rTMS on regional brain activity in depressed patients. Biol Psychiatry 48:1133-1141, 2000.

180. Nadeau SE, McCoy KJ, Crucian GP, Greer RA, Rossi F, Bowers D, Goodman WK, Heilman KM, Triggs WJ. Cerebral blood flow changes in depressed patients after treatment with repetitive transcranial magnetic stimulation: evidence of individual variability. Neuropsychiatry Neuropsychol Behav Neurol 15:159-175, 2002.

181. Mottaghy FM, Keller CE, Gangitano M, Ly J, Thall M, Parker JA, Pascual-Leone A. Correlation of cerebral blood flow and treatment effects of repetitive transcranial magnetic stimulation in depressed patients. Psychiatry Res 115:1-14, 2002. 
182. Nahas Z, Lomarev M, Roberts DR, Shastri A, Lorberbaum JP, Teneback C, McConnell K, Vincent DJ, Li X, George MS, Bohning DE. Unilateral left prefrontal transcranial magnetic stimulation (TMS) produces intensity-dependent bilateral effects as measured by interleaved BOLD fMRI. Biol Psychiatry 50:712720,2001

183. Teneback CC, Nahas Z, Speer AM, Molloy M, Stallings LE, Spicer KM, Risch SC, George MS. Changes in prefrontal cortex and paralimbic activity in depression following two weeks of daily left prefrontal TMS. J Neuropsychiatry Clin Neurosci 11: 426-435, 1999.

184. Speer AM, Willis MW, Herscovitch P, Daube-Witherspoon M, Shelton JR, Benson BE, Post RM, Wassermann EM. Intensitydependent regional cerebral blood flow during $1-\mathrm{Hz}$ repetitive transcranial magnetic stimulation (rTMS) in healthy volunteers studied with $\mathrm{H} 215 \mathrm{O}$ positron emission tomography: II. Effects of prefrontal cortex rTMS. Biol Psychiatry 54:826-832, 2003.

185. Peschina W, Conca A, Konig P, Fritzsche H, Beraus W. Low frequency rTMS as an add-on antidepressive strategy: heterogeneous impact on 99mTc-HMPAO and 18 F-FDG uptake as measured simultaneously with the double isotope SPECT technique. Pilot study. Nucl Med Commun 22:867-873, 2001.

186. Post A, Keck ME. Transcranial magnetic stimulation as a therapeutic tool in psychiatry: what do we know about the neurobiological mechanisms? J Psychiatr Res 35:193-215, 2001.

187. Muller MB, Toschi N, Kresse AE, Post A, Keck ME. Long-term repetitive transcranial magnetic stimulation increases the expression of brain-derived neurotrophic factor and cholecystokinin mRNA, but not neuropeptide tyrosine mRNA in specific areas of rat brain. Neuropsychopharmacology 23:205-215, 2000.

188. Kanno M, Matsumoto M, Togashi H, Yoshioka M, Mano Y. Effects of acute repetitive transcranial magnetic stimulation on dopamine release in the rat dorsolateral striatum. J Neurol Sci 217:73-81, 2004.

189. Ohnishi T, Hayashi T, Okabe S, Nonaka I, Matsuda H, Iida H, Imabayashi E, Watabe H, Miyake Y, Ogawa M, Teramoto N, Ohta Y, Ejima N, Sawada T, Ugawa Y. Endogenous dopamine release induced by repetitive transcranial magnetic stimulation over the primary motor cortex: an [11C]raclopride positron emission tomography study in anesthetized macaque monkeys. Biol Psychiatry 55:484-489, 2004.

190. Strafella AP, Paus T, Fraraccio M, Dagher A. Striatal dopamine release induced by repetitive transcranial magnetic stimulation of the human motor cortex. Brain 126 [Pt 12]:2609-2615, 2003.

191. Zangen A, Hyodo K. Transcranial magnetic stimulation induces increases in extracellular levels of dopamine and glutamate in the nucleus accumbens. Neuroreport 13:2401-2405, 2002.

192. Keck ME, Welt T, Muller MB, Erhardt A, Ohl F, Toschi N, Holsboer F, Sillaber I. Repetitive transcranial magnetic stimulation increases the release of dopamine in the mesolimbic and mesostriatal system. Neuropharmacology 43:101-109, 2002.
193. Strafella AP, Paus T, Barrett J, Dagher A. Repetitive transcranial magnetic stimulation of the human prefrontal cortex induces dopamine release in the caudate nucleus. J Neurosci 21:RC157, 2001.

194. Ben-Shachar D, Gazawi H, Riboyad-Levin J, Klein E. Chronic repetitive transcranial magnetic stimulation alters $\beta$-adrenergic and 5-HT2 receptor characteristics in rat brain. Brain Res 816 : 78-83, 1999.

195. Lisanby SH, Luber B, Schlaepfer TE, Sackeim HA. Safety and feasibility of magnetic seizure therapy (MST) in major depression: randomized within-subject comparison with electroconvulsive therapy. Neuropsychopharmacology 28:1852-1865, 2003.

196. Kosel M, Frick C, Lisanby SH, Fisch HU, Schlaepfer TE. Magnetic seizure therapy improves mood in refractory major depression. Neuropsychopharmacology 28:2045-2048, 2003.

197. Deuschl G, Wenzelburger R, Kopper F, Volkmann J. Deep brain stimulation of the subthalamic nucleus for Parkinson's disease: a therapy approaching evidence-based standards. J Neurol 250 [Suppl 1]:I43-I46, 2003.

198. Bejjani BP, Damier P, Arnulf I, Thivard L, Bonnet AM, Dormont D, Cornu P, Pidoux B, Samson Y, Agid Y. Transient acute depression induced by high-frequency deep-brain stimulation. N Engl J Med 340:1476-1480, 1999.

199. Stefurak T, Mikulis D, Mayberg H, Lang AE, Hevenor S, Pahapill P, Saint-Cyr J, Lozano A. Deep brain stimulation for Parkinson's disease dissociates mood and motor circuits: a functional MRI case study. Mov Disord 18:1508-1516, 2003.

200. Mayberg HS. Modulating dysfunctional limbic-cortical circuits in depression: towards development of brain-based algorithms for diagnosis and optimised treatment. Br Med Bull 65:193-207, 2003.

201. Drevets WC. Neuroimaging abnormalities in the amygdala in mood disorders. Ann NY Acad Sci 985:420-444, 2003.

202. Nuttin BJ, Gabriels LA, Cosyns PR, Meyerson BA, Andreewitch S, Sunaert SG, Maes AF, Dupont PJ, Gybels JM, Gielen F, Demeulemeester HG. Long-term electrical capsular stimulation in patients with obsessive-compulsive disorder. Neurosurgery 52 1263-1272 [discussion 1272-1274], 2003.

203. Mayberg HS, Lozano AM, Voon V, McNeely HE, Seminowicz D, Hamani C, Schwalb JM, Kennedy SH. Deep brain stimulation for treatment-resistant depression. Neuron 45:651-660, 2005.

204. McIntyre CC, Savasta M, Kerkerian-Le Goff L, Vitek JL. Uncovering the mechanism(s) of action of deep brain stimulation: activation, inhibition, or both. Clin Neurophysiol 115:1239-1248, 2004.

205. Herzog J, Volkmann J, Krack P, Kopper F, Potter M, Lorenz D, Steinbach M, Klebe S, Hamel W, Schrader B, Weinert D, Muller D, Mehdorn HM, Deuschl G. Two-year follow-up of subthalamic deep brain stimulation in Parkinson's disease. Mov Disord 18: 1332-1337, 2003. 